At the age of 10, Alfred Gilman wanted to go to the moon; on a visit to New York's Hayden Planetarium with his parents, he signed up to be an astronaut. Fifty years later, Gilman is preparing to take on a different, yet equally astronomical task. Instead of traveling to outer space, he is heading up a research program to detail the workings of cellular space.

\title{
Alfred Gilman
}

Among other things, Alfred Gilman is the director of the Alliance for Cellular Signaling (AfCS), a project that aims to characterize all proteins involved in cell signaling. The effort is the first to be funded by the US National Institute of General Medical Sciences under a new scheme-socalled Glue Grant fundingthat enables cooperation between investigators at multiple institutions (Nature Med. $6,1072 ; 2000)$.

Identifying all molecules in every signaling pathway and describing how they interact is a tall order, but 12 months

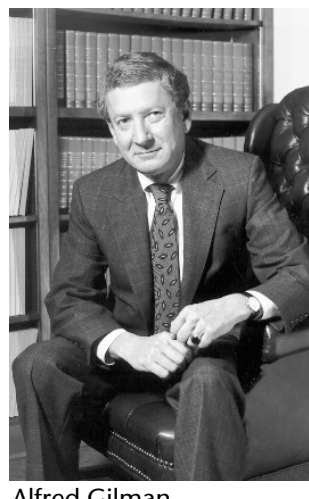
Alfred Gilman
Southwestern Medical Center Dallas for the past 20 years, where he counts other Nobel Prize winners such as Michael Brown and Joseph Goldstein as friends and colleagues. In order to take on the task of running AfCS, Gilman has substantially reduced the size and operations of own lab.

Perhaps because of his exemplary scientific lineage, achievements and working environment, Gilman is sensitive to the fact that believing one's own accolades can be a hindrance to research. At the first meeting of the AfCS, he posted a sign outside the meeting room that read, in AfCS already has the financial support of 2 other National Institutes of Health-the National Institute of Allergy and Infectious Diseases and the National Cancer Institute-6 pharmaceutical companies and 2 philanthropic organizations.

Each protein involved in signaling2,500 have been chosen to kick off the project-will have its own page on the AfCS website (http://www.cellularsignaling.org/). Each page will be evaluated by an editorial board and attributable to the author. The aim is to create a database that provides all information about a molecule of interest such as its protein structure and its relationship to other signaling molecules. The data aims to be so comprehensive that it will allow in silico creation of de novo signaling pathways.

What happened to Gilman's dreams of space travel and what qualifies him to lead such a major project in cell biology? In fact, Gilman was heavily influenced by his father, pharmacologist Alfred Gilman, co-author of Goodman and Gilman's world-renowned textbook, The Pharmacological Basis of Therapeutics, now in its 10th edition. Following early visits to his father's lab, young Gilman embarked on an $\mathrm{MD} / \mathrm{PhD}$ career, specializing in biochemistry. As for his cellular biology qualifications, Gilman was awarded the Nobel Prize along with Martin Rodbell in 1994 for the discovery of $\mathrm{G}$ proteins and their role in signal transduction.

Gilman has chaired the Department of Pharmacology at the University of Texas at
"Please leave egos at the door." He remembers, "There were a lot of heavy hitters coming into the room and we wanted to ensure a full and proper interactive discussion about collaborative science. It worked."

It was at that meeting that the decision was taken to study signaling in two cell types only, the mouse cardiac myocyte and B lymphocyte. That choice has attracted much criticism from cell biologists, specifically that it is limited and biased toward Gprotein signaling. Gilman defends the choice by insisting that an intense focus will enable highly reproducible observations and claims that if anything, the Alliance should have focused on only one cell type.

However, he also admits that the choice of cells is beset with problems. "We had our first annual meeting in Bethesda at the end of May, and everyone agreed that the progress is great but that substantial hurdles remain. For example, we can't maintain the mouse cardiac myocyte in culture for more than a day or so, which we need to be able to do so that we can manipulate gene expression in those cells. With the $\mathrm{B}$ lymphocyte, we're going to study an established B-cell line in parallel, but there's no corresponding myocyte cell line that we could use."

To overcome the problem, Gilman says that the AfCS is working on two separate approaches. First, his colleague in Dallas, Eric Olson, is developing a myocyte cell line and second, other AfCS scientists are trying to determine the conditions needed for isolation and culture of the myocyte that will permit their longerterm culture. Although the latter is possible for rat myocytes, it has not been done for the mouse. "We'll be able to keep the other laboratories working at full stretch whilst we develop the myocyte," says Gilman, "We're giving ourselves six months to a year to do this, and then if myocytes don't work we'll need to substitute a cell."

Another area that has attracted criticism is the apparent exclusion of groups outside the US on the grounds that most lack compatible computer hardware and operate on a different time zone. Gilman is not apologetic about this, that's not his style, but he does point out that the group is experimenting with connections to Mike Berridge's lab at the University of Cambridge, UK, and that groups as far away as Singapore and Australia have signed up to be members of AfCS, even though they cannot be participating investigators.

Glue Grant projects are intended to fund problems that can be solved in a 10-year time frame. "There is a specific endpoint to the project, which is to have a quantitative model of signaling systems in two cell types. Like all scientific projects though, new questions will continue to arise, so I don't think in a decade we'll know everything there is to know, but we will satisfy our goals of having good quantitative models of signaling pathways," says Gilman.

He recalls that after the initial meeting he sent a follow-up email to the 30 attendees asking their opinion of the project. One reply sticks out: "A certain scientist said that he was reluctant to get involved with problems where the answers would only come well after the time of his death. I think that's a troubling comment because firstly, he's an exceptionally bright individual and secondly, he's not that old!"

So would Gilman go to the moon tomorrow if he had the time? "I'd love to," he says, "although I don't like roller coasters and I'm not fond of being confined in small airplanes. But I'd like to see the view."

Karen Birmingham, London 